\title{
Influence of Initial Cell Densities of Cyclotella sp. on the Dominance of Microcystis aeruginosa under High N:P Ratio
}

\author{
Yoshimasa AMANO****, Motoi MACHIDA**** \\ *Graduate School of Engineering, Chiba University, 1-33 Yayoi-cho, Inage-ku, Chiba \\ 263-8522, Japan \\ **Safety and Health Organization, Chiba University, 1-33 Yayoi-cho, Inage-ku, Chiba \\ 263-8522, Japan
}

\begin{abstract}
This study examined the characteristics of M. aeruginosa (UTEX 2061) dominance under the existence of a competitor, Cyclotella sp. (CCAP 1070/4), at high N:P ratio through a series of culture experiments, and revealed the effects of initial cell density of Cyclotella $\mathrm{sp}$. on the dominance of $M$. aeruginosa as well. At N:P ratio of $140(P=0.1 \mathrm{mg} / \mathrm{L}), M$. aeruginosa could defeat Cyclotella sp., even though the initial cell density for $M$. aeruginosa was less than that for Cyclotella sp. Although it is generally accepted that the low N:P ratio favors the dominance of cyanobacteria, the results obtained in this study clearly indicate that the growth of $M$. aeruginosa would not depend on the low N:P ratio, and that $M$. aeruginosa could potentially dominate over other algal species in high N:P ratio. At N:P ratio of $1400(P=0.01 \mathrm{mg} / \mathrm{L}), M$. aeruginosa could become a superior competitor when the same initial cell density of 5,000 cells $/ \mathrm{mL}$ for $M$. aeruginosa and Cyclotella sp. was employed. The condition of higher initial cell density for Cyclotella sp. than that for M. aeruginosa was also examined. This experimental situation led to the dominance of Cyclotella sp. when a share of phosphorus concentration, $P_{s}$, was lower than the half saturation constant for M. aeruginosa.
\end{abstract}

Keywords: cell density, Cyclotella sp., Microcystis aeruginosa, N:P ratio, species dominance

\section{INTRODUCTION}

A number of observations in mesotrophic and eutrophic lakes have revealed that cyanobacterial blooms, mainly formed by Microcystis, tend to dominate over other phytoplankton species in warm season. The dominance of cyanobacteria would be attributed to nutrient salts, mainly phosphorus and nitrogen (Orr and Jones, 1998; Amano et al., 2002; Håkanson et al., 2007), as well as other factors such as light intensity (Varis, 1993; Litchman, 2003), temperature (Robarts and Zohary, 1987; Chu et al., 2007), flow rate (Kuwata and Miyazaki, 2000) and competitive interaction with other species (Nagai et al., 2007; Jin et al., 2009). Nitrogen to phosphorus mass ratio $(\mathrm{N}: \mathrm{P}$ ratio) is also well known as one of the key factors for cyanobacterial blooms. Cyanobacterial species tend to dominate when the N:P ratio is less than 29 (Smith, 1983), which is supported by several studies (Fujimoto et al., 1997; Jacoby et al., 2000). On the other hand, Xie et al. (2003) found that whether the N:P ratio was low or high, the cyanobacterium Microcystis could form blooms, and suggested that low N:P ratio would not be a cause but a result for cyanobacterial blooms. There have also been several reports that the succession of cyanobacterial blooms relates to the limiting nutrients rather than the N:P ratio (Sheffer et al., 1997; Reynolds, 1999).

So far, several studies were demonstrated to reveal the relationship between low N:P

Address correspondence to Yoshimasa Amano, Graduate School of Engineering, Chiba University,

Email: amanoy@faculty.chiba-u.jp

Received May 9, 2011, Accepted September 9, 2011. 
ratio (several tens of $\mathrm{N}: \mathrm{P}$ ratio) and cyanobacterial blooms. However, there is little information on the succession of cyanobacterial blooms in the region of relatively high $\mathrm{N}: \mathrm{P}$ ratio. In mesotrophic and eutrophic lakes, the reduction of nutrient salts for the purification of water quality has targeted phosphorus in many cases (Burley et al., 2001; Ottolenghi et al., 2002), which lead to the increase in N:P ratio. Thus, some experimental approaches would be needed to elucidate the characteristics of cyanobacterial blooms on high N:P ratio.

The objectives of this study were to examine the characteristics of cyanobacterial dominance under the existence of a competitor at high $\mathrm{N}: \mathrm{P}$ ratio through a series of competitive culture experiments, and to reveal the influences of the initial cell density of the competitor on the dominance of cyanobacteria. The outcomes of the competitive culture experiments were discussed based on the growth and nutrient uptake kinetics obtained through the single-species culture experiment.

\section{MATERIALS AND METHODS \\ Test alga}

Microcystis aeruginosa ( $M$. aeruginosa) was used as a representative species of cyanobacteria. As a competitor for M. aeruginosa, the diatom, Cyclotella sp., was employed because this species tends to be distributed in relatively many mesotrophic and eutrophic lakes. Microcystis aeruginosa and Cyclotella sp. were obtained from the Culture Collection of Algae at the University of Texas, USA (strain: UTEX 2061) and the Culture Collection of Algae and Protozoa, UK (CCAP 1070/4), respectively. Each species was grown in Woods Hole Chu (WC) medium $(N=14 \mathrm{mg} / \mathrm{L}, P=1.6 \mathrm{mg} / \mathrm{L})$ (Guillard and Lorenzen, 1972) in Erlenmeyer flask with the modification that the silicon concentration was adjusted to $11 \mathrm{mg} / \mathrm{L}$. The $\mathrm{pH}$ value in the medium was 8.0. All media were autoclaved at $121^{\circ} \mathrm{C}$ for $30 \mathrm{~min}$ before use. Both species were incubated at $20^{\circ} \mathrm{C}$ and at light intensity of $27 \mu \mathrm{mol}$ photons $/ \mathrm{m}^{2} / \mathrm{sec}$ with a light: dark cycle of $14 \mathrm{~h}: 10 \mathrm{~h}$. Each incubated flask was manually stirred several times a day.

\section{Determination of growth kinetics for M. aeruginosa and Cyclotella sp.}

The single-species culture experiment was conducted to examine the growth kinetics for M. aeruginosa and Cyclotella $\mathrm{sp.}$

A preculture was done prior to the culture experiment. Microcystis aeruginosa and Cyclotella sp. were separately grown in phosphorus-free WC medium for 7 days to allow them to adapt to a phosphorus-free environment. For the single-species culture experiment, $200 \mathrm{~mL}$ of $\mathrm{WC}$ medium in $500 \mathrm{~mL}$ Erlenmeyer flask with a phosphorus concentration of $0.005-0.5 \mathrm{mg} / \mathrm{L}$ was inoculated into the phosphorus-depleted culture for $M$. aeruginosa and Cyclotella sp. The initial cell density for each species was adjusted to 5,000 cells $/ \mathrm{mL}$. The culture experiment was continued until a stable phase for the growth was observed. Approximately $1 \mathrm{~mL}$ of aliquot for the medium was taken every 2 or 3 days for the measurement of cell density.

The growth rate $\left(\mu\right.$ day $\left.^{-1}\right)$ for M. aeruginosa and Cyclotella sp. in their growth phase was calculated in each phosphorus level based on the following equation: 


$$
\mu=\frac{1}{C} \frac{d C}{d t}
$$

where, $C$ and $t$ are the cell density (cells/mL) and cultivation time (day), respectively.

The half saturation constant $\left(K_{p}, \mathrm{mg} / \mathrm{L}\right)$ and maximum growth rate $\left(\mu_{m}\right.$, day $\left.^{-1}\right)$ for both species were estimated by Monod equation described as follows:

$$
\mu=\frac{P \cdot \mu_{m}}{P+K_{p}}
$$

where, $P$ is the initial phosphorus concentration $(\mathrm{mg} / \mathrm{L})$.

The experimental conditions were the same as mentioned above. The experiment was done in duplicate, and the results were presented as mean values $(\mathrm{n}=2)$.

\section{Measurement of phosphorus uptake of $M$. aeruginosa and Cyclotella sp.}

Phosphorus uptake rate for M. aeruginosa and Cyclotella sp. was determined through the phosphorus uptake experiment.

The experiment followed similar procedure as that of Marinho and Azevedo (2007). That is, an $800 \mathrm{~mL}$ WC medium in $1,000 \mathrm{~mL}$ Erlenmeyer flask with a phosphorus concentration of $0.1 \mathrm{mg} / \mathrm{L}$ was separately inoculated into the phosphorus-depleted medium of $M$. aeruginosa and Cyclotella sp. The initial cell density for each species was set to 5,000 cells $/ \mathrm{mL}$. Approximately $25 \mathrm{~mL}$ of aliquot was taken every $1-3$ days, and used for the measurements of phosphorus concentration and cell density. The phosphorus uptake experiment was run until the phosphorus concentration and cell density showed a stable phase.

The phosphorus uptake rate ( $V_{p}, \mathrm{mg} / \mathrm{cell} /$ day) was calculated by Eq. (3) when the rapid reduction of phosphorus concentration in the early stage of cultivation was observed. That is,

$$
V_{p}=\frac{\left(P_{1}-P_{2}\right)}{\left(C_{2}-C_{1}\right) \cdot\left(t_{2}-t_{1}\right)}
$$

where, $P_{1}, P_{2}, C_{1}$ and $C_{2}$ represent the phosphorus concentration $(\mathrm{mg} / \mathrm{L})$ and cell density (cells $/ \mathrm{mL}$ ) at the cultivation time of $t_{1}$ (day) and $t_{2}$ (day), respectively.

The experimental conditions were the same as mentioned above. The experiment was done in duplicate, and the results were presented as mean values $(\mathrm{n}=2)$.

\section{Competition between $M$. aeruginosa and Cyclotella sp.}

The competition experiment was performed to determine the predominant species between M. aeruginosa and Cyclotella sp.

Both high and low phosphorus concentrations of 0.1 and $0.01 \mathrm{mg} / \mathrm{L}$, respectively, for 
the culture media were prepared, of which the trophic states could be classified as eutrophic and lower-mesotrophic (Xu et al., 2001), and the resulting N:P ratios of the media were, therefore, $140(N=14 \mathrm{mg} / \mathrm{L}, P=0.1 \mathrm{mg} / \mathrm{L})$ and $1400(N=14 \mathrm{mg} / \mathrm{L}, P=$ $0.01 \mathrm{mg} / \mathrm{L}$ ), respectively. Two hundred milliliters of the prepared WC medium in 500 $\mathrm{mL}$ Erlenmeyer flask was inoculated into a mixture of phosphorus-depleted medium for M. aeruginosa and Cyclotella sp. The initial cell density for $M$. aeruginosa, $C_{0 \text {-Mic, was }}$ 5,000 cells $/ \mathrm{mL}$, while the different densities for Cyclotella sp., $C_{0-\mathrm{Cyc}}$, were 5,000, 25,000 and 50,000 cells $/ \mathrm{mL}$. An aliquot of the medium was taken every $2-3$ days, and was used for the determination of cell density. The experiment was run until the increase in growth rate for the dominant species of either M. aeruginosa or Cyclotella sp. showed less than 5\% (American Public Health Association, 1989). When closed cell densities for both species during the cultivation were exhibited, the experiment was continued until the replacement of dominant species seemed to be no longer observed. The experimental conditions were the same as previously mentioned. The competition experiment was conducted in triplicate, and the results were presented as mean values \pm standard deviation $(n=3)$. Dominant species at the end of the competition experiment was statistically determined by Student's $t$-test using Excel Statistics 2008 software (Social Survey Research Information Co., Ltd.). Cell density was determined through cell count using the plankton counting chamber (MPC-200, Matsunami Glass Ind., Japan) and binocular microscope under $300 \times$ magnification. Phosphorus concentration was measured according to the molybdenum blue spectrophotometric method (Japanese Standards Association, 1998).

\section{RESULTS}

\section{Growth and uptake kinetics for M. aeruginosa and Cyclotella sp. under phosphorus} limitation

The half saturation constant $\left(K_{p}\right)$, maximum growth rate $\left(\mu_{m}\right)$ and phosphorus uptake rate $\left(V_{p}\right)$ for $M$. aeruginosa and Cyclotella sp. are summarized in Table 1.

The $K_{p}$ value for $M$. aeruginosa was calculated to be $0.002 \mathrm{mg} / \mathrm{L}$, which was a relatively close value to $0.006 \mathrm{mg} / \mathrm{L}$ shown by Holm and Armstrong (1981). On the other hand, Cyclotella sp. showed one order higher $K_{p}$ value than that for M. aeruginosa and also the value of $0.003 \mathrm{mg} / \mathrm{L}$ for Cyclotella meneghiniana reported by Titman (1976). Although the $\mu_{m}$ value was not significantly different between $M$. aeruginosa and Cyclotella sp., the $V_{p}$ value was approximately 8 times higher for $M$. aeruginosa than that for Cyclotella sp.

Table 1 - Growth and uptake kinetics for M. aeruginosa and Cyclotella sp. under phosphorus limitation. Data presented are mean values \pm data range.

\begin{tabular}{cccc}
\hline Species & $\begin{array}{c}K_{p} \\
\mathrm{mg} / \mathrm{L}\end{array}$ & $\begin{array}{c}\mu_{m} \\
\text { day }^{-1}\end{array}$ & $\begin{array}{c}V_{p}{ }^{*} \\
\mathrm{mg} / \text { cell/day }\end{array}$ \\
\hline $\begin{array}{c}\text { M. aeruginosa } \\
\text { Cyclotella sp. }\end{array}$ & $0.002( \pm 0.0010)$ & $0.38( \pm 0.005)$ & $8.33 \times 10^{-9}\left( \pm 2.55 \times 10^{-9}\right)$ \\
\hline
\end{tabular}

*at $P=0.1 \mathrm{mg} / \mathrm{L}$ 
Characteristics of $M$. aeruginosa dominance under various cell densities of Cyclotella sp. at high $\mathrm{N}: \mathrm{P}$ ratio

Figure 1 (a) - (c) shows the results of the competition experiment between $M$. aeruginosa and Cyclotella sp.

At the initial cell density of 5,000 cells $/ \mathrm{mL}$ for each species and N:P ratio of $140, M$. aeruginosa completely dominated over Cyclotella sp. with the proportions of more than $99 \%$ in total cells $(t$-test, $p<0.01)$ in the final day of the experiment. The conditions with much higher $C_{0}$ of 25,000 and 50,000 cells $/ \mathrm{mL}$ for Cyclotella sp. caused the dominance of Cyclotella sp. until the cultivation time of day 8 and 15, respectively (Fig. 1(b) and (c)). However, M. aeruginosa finally dominated over Cyclotella sp. with the cell density of $7.4 \times 10^{5}$ and $5.9 \times 10^{5}$ cells $/ \mathrm{mL}$ at $C_{0 \text {-Cyc }}=25,000$ cells $/ \mathrm{mL}$ and $C_{0 \text {-Cyc }}=$ 50,000 cells $/ \mathrm{mL}$, respectively. In these conditions, the proportion of $M$. aeruginosa cells were respectively $97 \%$ ( $t$-test, $p<0.05)$ and 94\% ( $t$-test, $p<0.05)$ of total cell. On the other hand, at $\mathrm{N}: \mathrm{P}$ ratio of $1400, M$. aeruginosa became a superior competitor ( $t$-test, $p$ $<0.01$ ) when the same initial cell density of 5,000 cells $/ \mathrm{mL}$ was employed (Fig. 2 (a)), and the cell density reached $6.7 \times 10^{4}$ cells $/ \mathrm{mL}(90 \%$ of total cell $)$. However, the dominance of Cyclotella sp. was observed at $C_{0-\text { Cyc }}=25,000$ cells $/ \mathrm{mL}$ and $C_{0-\mathrm{Cyc}}=$ $50,000$ cells $/ \mathrm{mL}$ with ratios of $62 \%$ ( $t$-test, $p<0.05)$ and $65 \%$ ( $t$-test, $p<0.05)$, respectively (Fig. 2(b) and (c)).
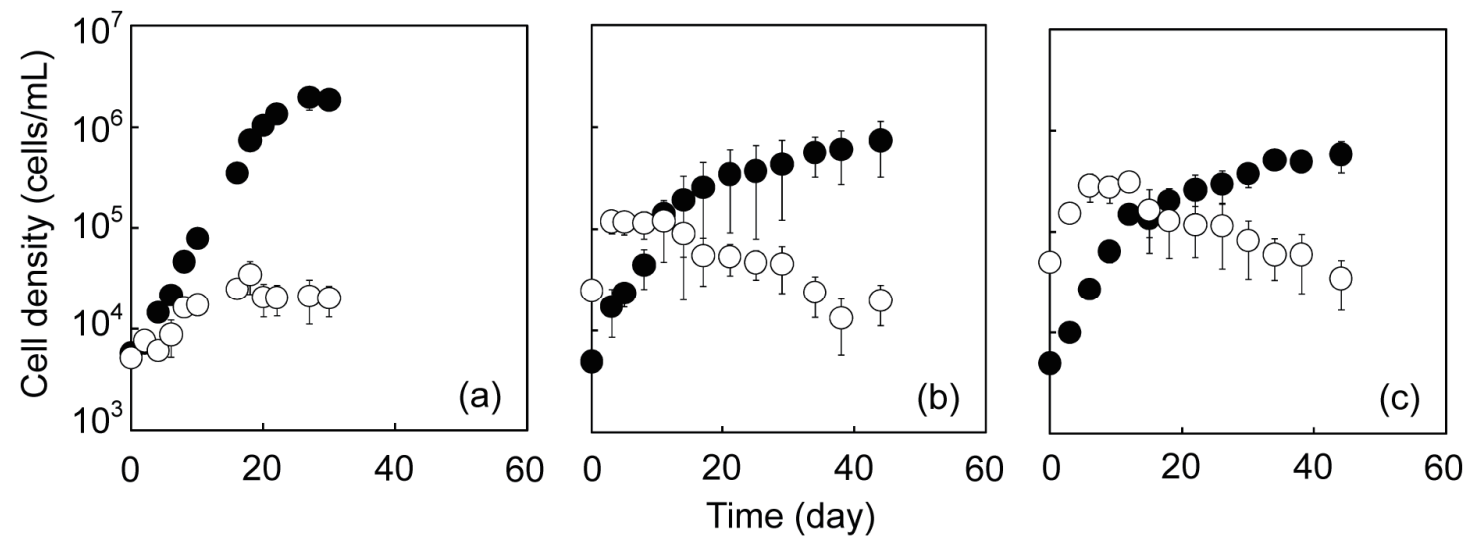

- M. aeruginosa o Cyclotella sp.

Fig. 1 - Characteristics of $M$. aeruginosa dominance under initial cell densities of (a) 5,000 cells $/ \mathrm{mL}$, (b) 25,000 cells $/ \mathrm{mL}$, (c) 50,000 cells $/ \mathrm{mL}$ for Cyclotella $\mathrm{sp}$. at $\mathrm{N}: \mathrm{P}$ ratio of $140(N=14 \mathrm{mg} / \mathrm{L}, P=0.1 \mathrm{mg} / \mathrm{L})$. Data presented are mean values \pm standard deviation $(\mathrm{n}=3)$. 


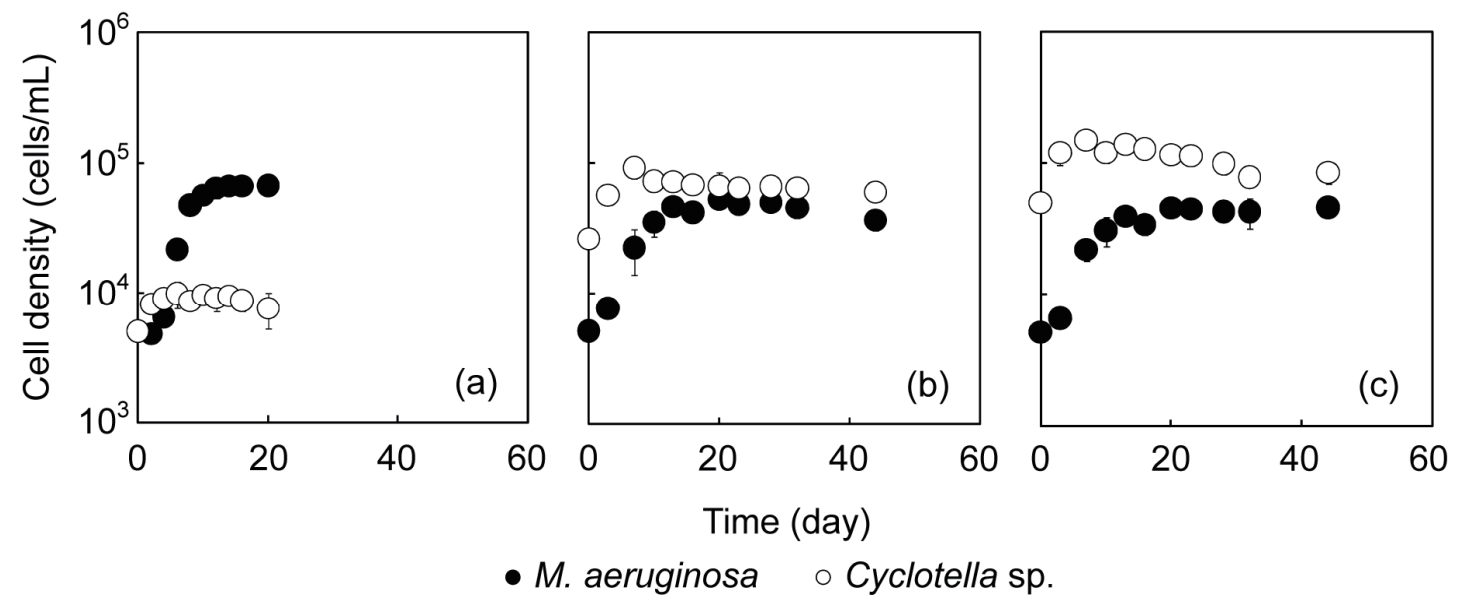

Fig. 2 - Characteristics of $M$. aeruginosa dominance under initial cell densities of (a) 5,000 cells $/ \mathrm{mL}$, (b) 25,000 cells $/ \mathrm{mL}$, (c) 50,000 cells $/ \mathrm{mL}$ for Cyclotella $\mathrm{sp}$. at $\mathrm{N}: \mathrm{P}$ ratio of $1,400(N=14 \mathrm{mg} / \mathrm{L}, P=0.01 \mathrm{mg} / \mathrm{L})$. Data presented are mean values \pm standard deviation $(\mathrm{n}=3)$.

\section{DISCUSSION}

Cyanobacterial and/or Microcystis blooms have conventionally been associated with low N:P ratio. Smith (1983) investigated 17 lakes worldwide to clarify the relationship between total nitrogen to total phosphorus mass ratio (TN:TP ratio) and the appearance of cyanobacteria, and suggested that cyanobacteria tended to appear at TN:TP ratio of less than 29. Smith et al. (1995) also revealed that the low TN:TP ratio of 22 favored the dominance of the $\mathrm{N}_{2}$-fixing cyanobacteria such as Anabaena and Aphanizomenon. Fujimoto et al. (1997) studied the growth abilities for M. aeruginosa and Phormidium tenue through continuous culture under various $\mathrm{N}: \mathrm{P}$ supply ratios, and revealed that $M$. aeruginosa dominated when the low supply of N:P ratio (less than 20) was conditioned. On the other hand, Xie et al. (2003) demonstrated in situ enclosure experiment with lake sediment and lake water including Microcystis to examine the relationship between TN: TP ratio and the occurrence of Microcystis blooms. Their results clearly indicated that the TN:TP ratio showed constant values of approximately $8-10$ with the appearance of Microcystis blooms even though the initial TN:TP ratio ranged between 10 and 60. These findings seem similar to the results of Sheffer et al. (1997), who reported that cyanobacterial blooms did not depend on TN:TP ratio, but phosphorus concentration. In our results, M. aeruginosa dominated over Cyclotella sp. at N:P ratio of 140 even the initial cell density for M. aeruginosa was less than that for Cyclotella sp. Furthermore, $M$. aeruginosa became a superior competitor at N:P ratio of 1,400 when the same $C_{0}$ with Cyclotella sp. was set. These results suggest that, when enough phosphorus concentration $(P=0.1 \mathrm{mg} / \mathrm{L})$ was fed, $M$. aeruginosa could become a superior competitor at $\mathrm{N}: \mathrm{P}$ ratio of 140 even though the $C_{0}$ of $M$. aeruginosa was less than that of Cyclotella sp., and that M. aeruginosa could defeat Cyclotella sp. at $\mathrm{N}: \mathrm{P}$ ratio of 1,400 when the same $C_{0}$ with Cyclotella sp. was used. Therefore, it could be concluded that the growth of $M$. aeruginosa would not depend on the low N:P ratio, and that $M$. aeruginosa could potentially dominate over other algal species in both low and high N:P ratio. 
The dominance of $M$. aeruginosa at the high $\mathrm{N}: \mathrm{P}$ ratios of 140 and 1,400 would be due to the smaller $K_{p}$ and higher $V_{p}$ values than those for Cyclotella sp. as shown in Table 1. Moreover, the competitive outcomes would also be attributed to the phosphorus storage ability of M. aeruginosa. Nakahara (1993) pointed out that $M$. aeruginosa could achieve cell division by 3.4 times in the phosphorus-limited condition, in which the value was higher than 2.2 in case of nitrogen limitation. This indicates that M. aeruginosa could survive under the phosphorus-limited condition consuming the stored phosphorus in the cell. Marinho and Azevedo (2007) experimentally examined the phosphorus uptake of $M$. aeruginosa, and reported that $M$. aeruginosa absorbed much phosphorus in the early stage of the cultivation, but the uptake became slower in the middle and late stages in the culture experiment. These trends would imply that $M$. aeruginosa could survive even under limited phosphorus by rapid uptake and storage of phosphorus in an earlier growth phase to exclude the other competitors.

Further discussion for the dominance of $M$. aeruginosa was simply made employing $K_{p}$, $V_{p}$ and $C_{0}$. At N:P ratio of $140(P=0.1 \mathrm{mg} / \mathrm{L})$ and $C_{0-\mathrm{Mic}}=C_{0-\mathrm{Cyc}}=5,000 \mathrm{mg} / \mathrm{L}(\mathrm{Fig}$. 1(a)), a share of phosphorus concentration, defined as $P_{s}$, for each species could be simply assumed as $0.05 \mathrm{mg} / \mathrm{L}$ based on the cell proportion of 1:1 for M. aeruginosa and Cyclotella sp. This concentration was much higher than the $K_{p}$ value for $M$. aeruginosa $(0.002 \mathrm{mg} / \mathrm{L})$ and Cyclotella sp. $(0.014 \mathrm{mg} / \mathrm{L})$, representing enough phosphorus concentrations for their growth. The dominance of $M$. aeruginosa in this condition would be due to the difference in $V_{p}$ values, i.e., the higher phosphorus uptake ability of $M$. aeruginosa would enable to take phosphorus from Cyclotella sp. Similarly, at $C_{0 \text {-Cyc }}$ $=25,000$ cells $/ \mathrm{mL}$ and $C_{0-\mathrm{Cyc}}=50,000$ cells $/ \mathrm{mL}$ (Fig. $1(\mathrm{~b})$ and (c)), the $P_{s}$ values could be estimated as 0.017 and $0.009 \mathrm{mg} / \mathrm{L}$, respectively, for each species. These $P_{s}$ values in both conditions were apparently higher than $K_{p}$ for $M$. aeruginosa, causing the dominance of $M$. aeruginosa. At N:P ratio of $1,400(P=0.01 \mathrm{mg} / \mathrm{L})$ and $C_{0-\mathrm{Mic}}=C_{0-\mathrm{Cyc}}=$ $5,000 \mathrm{mg} / \mathrm{L}$ (Fig. 2(a)), M. aeruginosa completely dominated over Cyclotella sp. because of lower $K_{p}$ than $P_{s}(0.005 \mathrm{mg} / \mathrm{L})$ as well as the higher $V_{p}$ contrary to Cyclotella sp. When the conditions of $C_{0-\mathrm{Cyc}}=25,000$ cells $/ \mathrm{mL}$ and $C_{0 \text {-Cyc }}=50,000$ cells $/ \mathrm{mL}$ were used, the outcomes of the competition experiment clearly led to the dominance of Cyclotella sp. (Fig. 2(b) and (c)). These results would imply that the prevention of $M$. aeruginosa dominance could be achieved at lower $P_{s}(0.0017 \mathrm{mg} / \mathrm{L}$ and $0.0009 \mathrm{mg} / \mathrm{L}$ at $C_{0-\text { Cyc }}=25,000$ cells $/ \mathrm{mL}$ and $C_{0-\text { Cyc }}=50,000$ cells $/ \mathrm{mL}$, respectively) than $K_{p}$ for $M$. aeruginosa and also higher cell density of Cyclotella sp. Despite the lower $P_{s}$ than $K_{p}$ for each species, $M$. aeruginosa could grow and achieve a cell density of approximately more than $10^{5}$ cells $/ \mathrm{mL}$. This would be due to the high phosphorus storage ability of $M$. aeruginosa.

A series of culture experiments indicated that $M$. aeruginosa could dominate not only at lower N:P ratio but also at higher ratio, i.e., at N:P ratios of 140 and 1,400. In spite of these facts, the dominance of $M$. aeruginosa at higher $\mathrm{N}: \mathrm{P}$ ratio was not often seen in yield observations. This would be due to the consequence of competition for phosphorus between $M$. aeruginosa and other species. Although M. aeruginosa dominated over Cyclotella sp. under the phosphorus-limited condition in this study, several sort of diatoms other than Cyclotella sp. would be favored by lower phosphorus condition. Tilman (1981) suggested that the half saturation constants for 4 kinds of common diatoms such as Fragilaria crotonensis, Asterionella formosa, Synedra 
filiformis and Tabellaria flocculosa ranged from $0.3 \mu \mathrm{g} \mathrm{P} / \mathrm{L}$ to $1 \mu \mathrm{g} \mathrm{P} / \mathrm{L}$, implying that these diatoms could easily outcompete $M$. aeruginosa because of much lower half saturation constant than that for $M$. aeruginosa $\left(K_{p}=0.002 \mathrm{mg} \mathrm{P} / \mathrm{L}\right)$. Therefore, the dominance of $M$. aeruginosa could be avoided by providing the conditions of lower phosphorus concentration, i.e., lower than $K_{p}$ for $M$. aeruginosa and higher cell density of the competitor.

\section{CONCLUSIONS}

This study examined the characteristics of M. aeruginosa (UTEX 2061) dominance under the existence of Cyclotella sp. (CCAP 1070/4) at high N:P ratio through a series of culture experiments, and revealed the effects of initial cell density of Cyclotella sp. on the dominance of M. aeruginosa. The conclusions can be summarized as follows.

1) At N:P ratio of $140(P=0.1 \mathrm{mg} / \mathrm{L})$, M. aeruginosa could defeat Cyclotella sp., even though the initial cell density for $M$. aeruginosa was less than that for Cyclotella sp. These experimental results indicate that the growth of $M$. aeruginosa would not depend on the low N:P ratio, and that $M$. aeruginosa could potentially dominate over other algal species in high $\mathrm{N}: \mathrm{P}$ ratio.

2) Microcystis aeruginosa could become a superior competitor at N:P ratio of $1,400(P$ $=0.01 \mathrm{mg} / \mathrm{L}$ ) when the same initial cell density of 5,000 cells $/ \mathrm{mL}$ for $M$. aeruginosa and Cyclotella sp. was set.

3) The condition of higher initial cell density for Cyclotella sp. than that for $M$. aeruginosa led to the dominance of Cyclotella $\mathrm{sp}$. when a share of phosphorus concentration, $P_{s}$, was lower than the half saturation constant for M. aeruginosa.

\section{ACKNOWLEDGEMENTS}

We would like to express our deep gratitude to Professor Dr. Masami Aikawa of Kisarazu National College of Technology and Professor Dr. Keiichi Nagao, Head of Safety and Health Organization, Chiba University, for their useful comments and suggestions.

\section{REFERENCES}

Amano Y., Taki K., Murakami K., Ishii T. and Matsushima H. (2002) Sediment remediation for ecosystem in eutrophic lakes. The Scientific World JOURNAL, 2, 885-891.

APHA (1989) Standard Methods for the Examination of Water and Wastewater. 17th edn, American Public Health Association/American Water Works Association/Water Environment Federation, Washington DC, USA.

Burley K. L., Prepas E. E. and Chambers P. A. (2001) Phosphorus release from sediments in hardwater eutrophic lakes: the effects of redox-sensitive and -insensitive chemical treatments. Freshwater Biol., 46 (8), 1061-1074.

Chu Z., Jin X., Iwami N. and Inamori Y. (2007) The effect of temperature on growth characteristics and competitions of Microcystis aeruginosa and Oscillatoria 
mougeotii in a shallow, eutrophic lake simulator system. Hydrobiologia, 581 (1), 217-223.

Fujimoto N., Sudo R., Sugiura N. and Inamori Y. (1997) Nutrient-limited growth of Microcystis aeruginosa and Phormidium tenue and competition under various N:P supply ratios and temperatures. Limnol. Oceanogr., 42 (2), 250-256.

Guillard R. R. L. and Lorenzen C. J. (1972) Yellow-green algae with chlorophyllide c. J. Phycol., 8 (1), 10-14.

Holm N. P. and Armstrong D. E. (1981) Role of nutrient limitation and competition in controlling the populations of Asterionella formosa and Microcystis aeruginosa in semicontinuous culture. Limnol. Oceanogr., 26 (4), 622-634.

Håkanson L., Bryhn A. C. and Hytteborn J. K. (2007) On the issue of limiting nutrient and predictions of cyanobacteria in aquatic systems. Sci. Total Environ., 379 (1), 89-108.

Jacoby J. M., Collier D. C., Welch E. B., Hardy F. J. and Crayton M. (2000) Environmental factors associated with a toxic bloom of Microcystis aeruginosa. Can. J. Fish. Aquat. Sci., 57 (1), 231-240.

Japanese Standards Association (1998) JIS K0102 Testing Methods for Industrial Wastewater, Japanese Standards Association, Ed. Namiki, H., Tokyo, Japan. (in Japanese)

Jin X., Chu Z., Yan F. and Zeng Q. (2009) Effects of lanthanum (III) and EDTA on the growth and competition of Microcystis aeruginosa and Scenedesmus quadricauda. Limnologica, 39 (1), 86-93.

Kuwata A. and Miyazaki T. (2000) Effects of ammonium supply rates on competition between Microcystis novacekii (Cyanobacteria) and Scenedesmus quadricauda (Chlorophyta): simulation study. Ecol. Model., 135 (1), 81-87.

Litchman E. (2003) Competition and coexistence of phytoplankton under fluctuating light: experiments with two cyanobacteria. Aquat. Microb. Ecol., 31 (3), 241-248.

Marinho M. M. and Azevedo S. M. F. O. (2007) Influence of N/P ratio on competitive abilities for nitrogen and phosphorus by Microcystis aeruginosa and Aulacoseira distans. Aquat. Ecol., 41 (4), 525-533.

Nakahara H. (1993) Chanophyceae. In: Effect of $\mathrm{N}: \mathrm{P}$ ratio in water on aquatic organisms, Ed. Yoshida, Y., pp.39-50, Kouseisya-Kouseikaku Press, Tokyo, Japan. (in Japanese)

Nagai T., Imai A., Matsushige K. and Fukushima T. (2007) Growth characteristics and growth modeling of Microcystis aeruginosa and Planktothrix agardhii under iron limitation. Limnology, 8 (3), 261-270.

Orr P. T. and Jones G. J. (1998) Relationship between microcystin production and cell division rates in nitrogen limited Microcystis aeruginosa cultures. Limnol. Oceanogr., 43 (7), 1604-1614.

Ottolenghi F., Qin J. G. and Mittiga L. (2002) Enhancement of phosphorus release from lake sediments by aeration and crayfish activity. J. Freshwater. Ecol., 17 (4), 635-640.

Reynolds C. S. (1999) Non-determinism to probability, or N:P in the community ecology of phytoplankton. Arch. Hydrobiol., 146 (1), 23-35.

Robarts R. and Zohary T. (1987) Temperature effects on photosynthetic capacity, respiration, and growth rates of bloom-forming cyanobacteria. N. Z. J. Mar. Freshw. Res., 21 (3), 391-399.

Sheffer M., Rinaldi S., Gragnani A., Mur L. R. and van Nes E. H. (1997) On the 
dominance of filamentous cyanobacteria in shallow, turbid lakes. Ecology, 78 (1), 272-282.

Smith V. H. (1983) Low nitrogen to phosphorus ratios favor dominance by blue-green algae in lake phytoplankton. Science, 221 (4611), 669-671.

Smith V. H., Bierman V. J., Jones B. L. and Havens K. E. (1995) Historical trends in the Lake Okeechobee ecosystem IV. Nitrogen:phosphorus ratios, cyanobacterial dominance, and nitrogen fixation potential. Arch. Hydrobiol. Suppl., 107 (1), 71-88.

Titman D. (1976) Ecological competition between algae: Experimental confirmation of resource-based competition theory. Science, 192 (4238), 463-465.

Tilman D. (1981) Tests of resource competition theory using four species of Lake Michigan algae. Ecology, 62 (3), 802-815.

Varis O. (1993) Cyanobacteria dynamics in a restored Finnish lake: a long term simulation study. Hydrobiologia, 268 (3), 129-145.

Xie L., Xie P., Li S., Tang H. and Liu H. (2003) The low TN:TP ratio, a cause or result of Microcystis blooms? Water Res., 37 (9), 2073-2080.

Xu F.-L., Tao S., Dawson R. W. and Li B.-G. (2001) A GIS-based method of lake eutrophication assessment. Ecol. Model., 144 (2-3), 231-244. 